\title{
Talking drums and ethical conundrums
}

\author{
By Ruth Goldstein (University of California, Berkeley)
}

\begin{abstract}
Malian women and children represent the poorest as well as the most difficult to reach through written media. The interrelated practices of dancing, drumming, and storytelling transmit history, cultural beliefs, and current events for people who do not read and write. Researchers in the social sciences and officials for international aid organizations struggle with the circulation and reception of public health literature. They now recognize that native non-governmental organizations with staff that are fluent not only in the native languages but also in the social mores, better communicate with underserved populations through means other than billboards, pamphlets, or power-point presentations. The body, in both a general Western and Malian tradition, plays a particular role in how we come to know the world. This paper describes research conducted in Mali on female circumcision with international aid organizations, native NGOs, and independent human rights activists. Three interconnected areas form a triangular framework: how different research methods like dancing, drumming, storytelling, and soccer can offer valuable phenomenological insights to lived experience; the ethics of learning and listening to these various voices that transmit sexual health knowledge; and the ethics of engaging and disseminating such knowledge. The talking drums elicit new ways of seeing, being, and listening along with ethical ethnographic conundrums.
\end{abstract}

The sun had sunk to a deep crimson line on the horizon when I first arrived and boarded a Sotrema, the Malian public transport bus. The few trees that graced the landscape glowed green against the red earth. No glass covered the windows and the warm air blew freely, packed with pockets of red dust that settled on my arms. The Sotrema crossed the old bridge bringing me closer to my field site and host family in Doumanzana, fifteen kilometers outside of Bamako. The river appeared serene and wide. Underneath the tranquil waves I thought I could make out the shapes of crocodiles and hippopotami. "Mali" in Bambara means "hippopotamus" and "Bamako," Mali's capitol city, means "crocodile." Both species have come close to extinction in Mali. The colonial era saw the decimation of wildlife. Poverty and lack of natural resources in Mali continue to challenge both animal and human survival.

"Don" in Bambara means "to dance"; it also means "to know." When I first arrived in Mali in August of 2001, I spoke no Bambara. I had come on a Thomas J. Watson fellowship to study women's human rights and health reforms that followed the resolutions drafted during the 1994 United Nations conference on Population and Development (ICPD) and the Fourth World Conference on Women that occurred the following year. Both conferences had recently reconvened for five year follow-up sessions, both of which I had initially followed as a journalist. The challenges of implementing internationally-acknowledged human rights reforms in countries whose cultural practices were deemed human rights violations formed the basis of my research. The primary concern of governmental and nongovernmental 
agencies working in Mali was "éxcision" or "muso bolokolen," otherwise known in English as female circumcision, or less euphemistically, as female gential mutilation (FGM). Female Genital Cutting (FGC) has now replaced FGM as the dominant acronym in anthropological discourse, so I use it even as many NGOs continue with the latter.

I had come to work with UNDP, USAID, and UNICEF. I soon realized, however, that I would be better able to learn about Malian conceptions of women's human rights with Malian NGOs and individuals. In making this switch I had to learn to speak Bambara or "bamanankanfo" with more fluency. Living with a Malian family, two wives and fourteen children made this process somewhat easier. But learning the language entailed more than studying the spoken word and speaking it involved more than just thinking in it. I had to "know" in it. I had to dance. Embodying the language, its tones and boundaries, through dance and drumming enabled me to deepen my connections, not just to the women but also to the men. The men, I realized, were constantly left out of women's human rights conversations, which, in the case of FGC, has potentially adverse effects. Men do have a say, and often in the legal sense, they have the most say. Ignoring their voices and thoughts weakens any move to change the practice of FGC.

The various UN, governmental, and nongovernmental agencies circulated sexual health information in pamphlets, on billboards, and in powerpoint presentations. Public health care workers frequently voiced their frustration at how little progress they felt they made in the eradication of FGC, but they had very little contact with Malians on a daily basis or a facility with the Bambara language. They also focused only on trying to reach the women. The Malian NGOs that I worked with, on the other hand, approached the taboo subject of sex with both men and women and they did so through dance, drumming, storytelling, and soccer.

In Western, and as I believe in Malian tradition, the body plays an important role in how we come to know the world. I choose not to say "see" because of an ingrained "occularcentrism"1 even though "seeing" can involve all of the senses and operate below the radar of congnition. What could not conveyed in textual or spoken form could be sung and danced, that is, quite literally, it became situated body knowledge-apprehended and transmitted physically, invoking all the senses and the spirits.

This paper is about coming to know and research different ways of being-in-the-world by looking, speaking, listening, and ultimately experiencing differently. Listening to the talking drums speaks to the ethical conundrums involved in trying to know the world differently. This is a perspective that explores a dialogic construction of identities and a multidimensional sense of self where language incorporates movement and sound. It is a perspective that cannot resolve but instead considers the polarities of cultural relativism and universal human rights laws through ethnographic experience and anthropological writings on the self, the body, and rights. It is an exploration of questions surrounding how methods in anthropology might be construed as a kind of humanitarian intervention. It asks whether and when such interventions lie within the expanding scope of anthropological inquiry. This is not to offer a solution or even a history of anthropological engagement with human rights, but rather to underline why it is so important to keep open the inquiry of "anthropos." 
While this paper is not directly a critical evaluation of accepted reseach methods in (medical) anthropology or of public health initiatives, it does indirectly highlight the shortcomings of assuming a "developing world subject" within a liberal multicultural ideology. As Michael Lambek points out in his forward to Wendy James' The Ceremonial Animal, North American anthropology has had difficulty defining itself as its "traditional" subjects have "disappeared" from the world stage. ${ }^{2}$ Or as such subjects have become something other than premodern. The subsequent breakdown into subdisciplines produced a jostling for a recognized place and role. More than in any of the other subdisciplines, medical anthropology has a presence in human rights issues.

Neither a vehicle for vilifying nor for vindicating the practice of any type of circumcision, this paper probes at the seemingly solid foundations of what constitutes human rights and ethnographic (ab)uses. According to article 39 of the Beijing Platform for Action on Women, female genital mutilation-never referred to as circumcision-represents a violation to women's human rights. ${ }^{3}$ Female circumcision is, at best, a touchy subject for public health organizations and a complicated object of inquiry for (medical) anthropologists. While anthropology as an international discipline does not have an explicit code of ethics, regulations, or a published perspective on human rights, this article suggests that because "anthropos" is the fundamental focus of anthropology, it is hard to see how anthropologists can avoid being implicated.

What role the anthropologist has in international debates on human rights has been part of an international question since the drafting of the Universal Declaration of Human Rights (UDHR). Anthropology, or perhaps it is only North American anthropology, became involved when the United Nations Educational, Scientific and Cultural Organization (UNESCO) called upon Northwestern University's Melville Herskovits for his opinion. A former student of Franz Boas, Herskovits wrote a 'Statement on Human Rights' in favor of honoring cultural differences and against a universalizing declaration on human rights. The American Anthropologist published his piece one year before the UDHR was drafted. In 1999, fifty-two years later, the American Anthropology Association voted on a document entitled "Declaration on Anthropology and Human Rights."4 The declaration promulgated a more definitive stance towards and engagement in human rights issues, but not an standardized prescription. How, when, and if anthropologists take part in human rights and humanitarian issues ultimately remains the researcher's decision.

My ethnographic experiences weave in-and-out of the theoretical fabric of this paper. I also thread in a thin summary of the history of female circumcision. I conclude not by answering what the anthropologist's role should be with respect to female circumcision or to human rights work but with the hope that such questions about what constitutes "the human" and human rights remain open and perhaps even spawn new ones. Such openness to news ways of listening, seeing, and writing may then engender cross-cultural dialogue about human rights even as we deconstruct the very concepts of "culture" and "the human." Language, voice, and different forms of knowing thus play a significant role, not simply in the spoken word or written word, but in the gestural and embodied sense(s) as well. 
The written as well as the body language of suffering points to different ways of accessing and knowing the world. Mariela Pandolfi writes about "a metacultural process of creating polysemic and multilevel sense of self" (Pandolfi 1990: 255) in her article "Boundaries Inside the Body: Women's Sufferings in Southern Peasant Italy." Her words resonate with Malian Sufi Master Amadou Hampate Bâ's explication of the Malian proverb that the "people of the person are many" (Bâ 1972: 11). Pandolfi outlines a connection between the interpretation of suffering and illness in Southern Italy, looking at multiple layers and understandings of one person's selves and others' selves through the language of the body (in suffering). Bâ's words open up ethical possibilities (and pitfalls) for the ethnographer by pointing to multiple perceptions/conceptions of "the human" and ways of being human. The people of the person can be many in that it the person is never sui generis of the culture or that the person him or herself contains multiple selves within the epidermal boundary of the body. The concept and the various ways of reading "the people of the person are many" in addition to João Biehl's Vita: Life in a Zone of Abandonment, have formed the subterranean flow of my thinking about the tension between cultural relativism and universal human rights.

In the first section of this paper I will focus on conversations that take up the ethics of conducting ethnographic research-listening, speaking, and writing. In the second section, I will discuss the ways in which these practices center on how and where we perceive "the self" or the identity of a person and of a culture to be located. The third section follows from the location, or in many circumstances, the dislocation of self, to competing notions of "the human"- and/or "anthropos" because the two, as Paul Rabinow points out, are not always the same. It is the assumption of what constitutes "the human," as dicussed in the third section, that then shapes how we think about constitutes "the exhuman" (Biehl 2005: 24) and "inhuman" cultural practices.

The very act of thinking is a vehicle for transforming, in Foucauldian terms, the "constative to the subjunctive, from the singular to the multiple, from the potential to the virtual (Rabinow 2002: 139). This kind of thinking either infects or reflects, depending on one's positionality, the circulation of human rights discourse. Who has the authority to speak and to speak morally depends on who has the ability to think rationally. Logos means both reason and speech for Aristotle in his Politics (Aristotle 1984). He understands Nature as an intentional and ordered designer, endowing man with speech and the ability to discern good from evil. The speech-reason couplet resonates with the talking drums and dancing bodies but there are other ways of speaking that do not include the voice.

There are other ways "to know"- "Don"—or dance and perhaps there are different definitions of good and evil. It became central to me to understand where others placed me as an observer, listener, friend, confident, specialist — and where I positioned myself. I did think differently as I expressed myself in Bambara as well as with and through the talking drums. I started off unsure of where to locate myself vis-à-vis FGC and I cannot say that my stance became more clear, only that I came to understand the cultural and human rights issues on a deeper level. I adopt an attitude similar to that of Bettina Shell-Duncan, that it "becomes clear that careful deliberation is required to develop action strategies that offer both protection and respect for the culture and autonomy of those women and families concerned. ${ }^{5}$ 


\section{Ethical Speech Acts and Listening}

The talking drums communicate with the audience, with the dancers, and with each other. The head drummer controls the rhythm and the tempo for the other drummers, but the conversation between the head drummer and dancer are ongoing conversations. Almost always it is the men who drum and the women who dance. The drummers can dictate the tempo at the end of a dance or set, but a good head drummer listens to the movements of the dancer and follows her lead. The flow of communication does not have to end with the event; the same drummers and dancers meet again and again in open-ended musical conversation. How might this translate or begin to be equated in ethnographic research?

João Biehl's ethnography is a speech act addressed both to Catarina, his main interlocutor, and to us, the readers. He attempts to conduct an anthropology of affliction that keeps open the questions about human life punctuated by suffering. He refuses to write one conclusion that holds rigid as the one truth, as the "reality." As an author, Biehl creates his identity dialogically. Catarina's words compel him to act and define his ethnographic practice just as Catarina's "dictionary," as she calls it, helps her define her identity through language. The dictionary is more poetry than prose and explains people and memories through words, rather than the words themselves. Biehl sees her as dwelling "in the luminous lost edges of a human imagination that she expanded through writing" (Biehl 2005: 14). It is by traveling along these edges, tugging at the frayed fibers of life that he discovers the violent reality obscured beneath the banality of the everyday. In doing so, he sees and creates a picture of the human condition, which is he understands to be "ethnography's core object of inquiry" (Ibid).

Language in a dictionary like Catarina's relies on a different kind of semantic organization and cannot simply be read, but must also be felt. Such are the acts of dancing and drumming, where ideas pass from person to person through body language-finger-words and footwords, relaying as much as the spoken word. The speaking of Bambara resonates with the tonal language of the drums. Two words might be phonetically identical, but can mean two different things. I learned this lesson quickly. The example that the children in my family had given me was of: "So" meaning "horse" - in a low tone and "So!" meaning "house," in a high tone. "Kulu" in a low tone means dog. "Kulu" in a high tone refers to a particular part of male anatomy. This is the mistake that I made, as people often do, calling an anonymous animal by its species' name in a high-pitched voice.

In a similar fashion to the duality of tone and meaning, I came to signify two people at once. ${ }^{6}$ I had my high tones and my low tones as well as my high and low emotions that I brought with me or that just came out into bodily movements. As Ruth Goldstein, the white Jewish girl from Baltimore City, I could ask about certain cultural practices but I was also Kadja Coulibaly, as hailed by my Malian host family, who could not ask but could participate in other cultural practices. This is not to say that the two characters did often conflate in my own mind and in the social interplay between myself and others. Where the divisions and the overlaps lay between my two selves was not always clear to me, but this illuminated all the more that how something is said, not just what is said, can shape the possibilities for the present and future (as well as how people experience the past). 
In Bambara the future tense does not exist. To project an action from the present or past the speaker has to use tomorrow, which could mean any day or at any time. The past and the present coexisted with what I preceived as the future. Only two tenses could make Bambara easy to learn, were it not for the tones. Listening took on an intentionality as never before. Without body language, deciphering the difference between the possible meanings of a word pronounced the same but with variations of tone, making mistakes like "kulu" came easily.

It was the lack of having a future tense and the shock that my Malian host sisters would ask me about circumcision that initially left me without the words to respond. I had been living for a month with the Coulibaly family - two wives, fourteen children, and various aunts, uncles, and cousins bringing the total number to somewhere near thirty five people. I had made it clear, in both Bambara and in French, that I was researching female circumcision, that I was working with a Malian organization, and that I was interested in what Malians, not just Westerners, had to say about Mali and the practice of FGC. I was not sure what I thought my role or any foreigner's role should or could be. The invitation lay open for them to tell me and for me to listen.

Charles L. Briggs writes of the inequities ingrained the researcher or interviewer-interviewee relationship in "Learning How to Ask: A sociolinguistic appraisal of the role of the interview in social science research." Questions often come framed, knowingly or not, in the interviewer's cultural beliefs and communicative practices. These "metacommunicative" practices assign certain kinds of meanings and understandings to the interview event. They invoke the interviewer's understandings of the world and do not fully, if at all, engage the researcher in the world of the other person or persons (Briggs 1986). No doubt, this produces a distorted, if not rehearsed and expected cultural viewpoint from the interface. Perhaps a way to circumvent this is to look closely at one's self and one's own practices, constructing not a metacommunicative event but an intercultural dialogue.

Assetan and Miriam, two female cousins pulled up stools and sat next to me, our backs supported by the only cement wall of the house. Fanta and Poupée, the two eldest daughters of the first wife followed her lead. We had danced together the night before and the whole week before that. Weddings, baptisms, and school vacation parties had us outside the home compound almost every day but never late into the night. I had gone with other Malian friends to "djinidons" spirit dances, and the girls had simply raised their eyebrows when I told them where I had been.

The three girls started to strip potato leaves and grind them into a paste for a sauce called saga-saga. "Kadja be na"- "Kadja come here," Assetan said, beckoning me with a nod of her head. She had christened me Kadja the day I arrived, after the prophet Muhammad's first wife. "An be baarake na baaroke"- "We are working and chatting." I reached my hand into the pile of green and started to shred with them, inspecting the leaves for brown spots or worms. We sat quietly, listening to the battery-operated radio while the two sons of the second wife, Alhassan and Musa, began to pour sugar to make the afternoon tea. Adam, an American studying dance and drumming, joined our circle, sitting down quietly to write in his journal. 
Abruptly Assetan turned to me: "Ask Adam if his girlfriend is muso bolokolencircumcised."

Stunned, I did not respond immediately. Muso bolokolen literally means "woman of bloody hand." Bolo normally refers to the hand, but in this particular instance it is a euphemism for the clitoris. Bolokoli refers to the act of cutting. A muso bolokolen is a circumcised woman. I had wanted to discuss the issue with the girls but I had not dared bring it up for fear of offending them.

"Ask Adam if his girlfriend is circumcised," insisted Assetan, pulling me out of my shock.

Adam looked up from his journal when he heard his name.

"What's up?"

Assetan dropped her eyes and bent her head.

"The girls want to know," I said in English, "if Megan is circumcised."

Adam laughed loudly. "What? Heck no! No way." He shook his head. "Tell them we don't do that in America."

"No," I simply translated into Bambara. "She isn't circumcised."

"But why did he laugh?" The girls all wanted to know.

"He just laughed because it's very uncommon, well, actually it's unheard of for an American woman to be circumcised."

"How would he know? Miriam teased, but Assetan interrupted her.

"Why isn't she circumcised? All the women here are circumcised. If you aren't, you are a bad Malian woman." She looked upset and I wished that I had not smiled when Miriam first posed her question. I did not want them to think that Adam and I were making fun of them. I had spoken openly about my research with the Coulibaly adults, but we had never spoken directly about female "excision" in the family.

"We don't think a woman is bad if she hasn't been circumcised." I said.

"But why? The girls' faces have pulled into masks of suspicion and worry. "Women must have it, otherwise they will meet men late at night and do bad things with them. If you are not circumcised you cannot marry a man and you live in shame." Assetan said. She was frowning.

I paused before answering, not sure how to proceed. "But what about me? I am not circumcised. Do you think I am bad? I don't go out at night in search of men." 
"Maybe it is different for you, for Americans. Maybe you don't need it, but we do." I realized that because of my closeness with the girls they could ask me these questions, but at the same time, I was an American woman who wasn't circumcised, giving me more power to hurt their feelings if I asked the (wrong) questions. Adam's presence provided a way around this.

"Adam, maybe if the questions come from you then maybe they won't feel offended."

"Oh, so you're gonna make me the bad guy, huh?"

"No, I think that because you are a guy, an American guy, you have an excuse to ask the questions. Boys here aren't supposed to know about this stuff. I doubt they would even be able to tell the difference between a circumcised woman and one who still has everything intact. If you ask, it's neutral. If I ask, it's criticism."

"Okay," Adam agreed. "Just remember to tell me later what I have been asking."

"Adam should marry a Malian woman." Miriam said. "Like me. I can cook and clean for him, and I am circumcised."

I translated to Adam and he replied that there was no way he will marry a circumcised woman. 'Why did they want to know this?' He wondered. 'What was behind it?' His fascination did not keep him from noticing how he enabled this conversation.

"I don't think I could have this exchange without you here, Adam. Thank you. I don't know if the girls would have come so directly to these questions. They really want to know about this but I think I am too anatomically close to ask without you acting as some kind of intermediary."

"Well, perhaps you are too anatomically intact. But I think they would have talked to you, just in a really different and roundabout way. That seems to be pretty Malian, that roundabout way."

"What did he say? Why the look on his face? What are you two talking about? Tell us!" Assetan and Miriam sat with hands on one another's knees, eyes on me expectantly while Fanta and Poupée have pulled their stools closer to Adam.

I felt odd being the interpreter. Adam enabled a particular kind of dialogue between all of us and because he did not speak French or Bambara with this kind of fluency. I turned first to Adam and asked him if he minded whether or not I asked some questions that I could say came from him again.

"Sure. Just translate for me, ok?"

“Ok." 
I turned to the girls and Musa and Alhassan who had sat down on the ground next to Adam, pouring tea for all of us and listening intently.

"Adam wanted to know if all Malian women are circumcised and why."

The four girls sighed but they seemed eager to answer Adam's question. "You know," Assetan began, "women in the north like the Touregs aren't circumcised. But if they marry a man from the south, like a Bambara man, she must become muso bolokolen, otherwise the man's family is shamed."

"So it is up to the man?" I asked.

"What do you mean?" Assetan said. "Men have nothing to do with it."

"But..." I turned to Adam and explained that I wanted to ask that if the husband does or does not care if the woman can remain uncircumcised but Assetan interrupted me.

"You don't understand Kadja. Women here... us... Malian women... We must do it. It makes childbirth easier. It makes all female things easier. We cannot survive without it. It is wrong to be any other way. Tell Adam that, too."

I translated to Adam. "Wow. That's all the reasons it is bad. It is harder, more painful and potentially fatal for women in childbirth, isn't it?"

"Yes."

"Not to mention how painful sexual intercourse must be." Adam paused and then said quietly. "She seems pretty upset, though. She needs us to agree with her."

I looked at Assetan, regarding us intently, the potato leaves forgotten in her lap.

"Does Adam understand? Did you tell him what I said?"

"I did."

"And does he still want an uncircumcised woman? Doesn't he now want a Malian woman instead?"

“Assetan, he can't make that choice now. The choice is not for his head. It is for his heart.

The girls all looked at each other. "I like that." Assetan said slowly. "The heart, the son decides."

"Would you marry a toubab?"7 I asked the girls.

"No!" Fanta and Assetan declared. But Miriam stayed silent and looked furtively at Adam. 
"Why not? You want Adam to choose a Malian woman, but you yourself won't marry a toubab? How is that fair?"

"I just want to know if he would choose a Malian woman over an American one, that's all. I like toubabs as friends, but not for husbands."

Adam and I said nothing. It occurred to me that all Assetan wanted to know was whether we thought Malian women were as good as American women. She wanted to know how they compared. Which was more feminine? But then, Malian and American ideas of womanhood seem to vary. I found myself wanting to sit closer to Assetan, feeling my own understandings of the social and cultural mores in which I had grown up sway from their moorings.

Alhassan stirred his pot of tea and Musa poured more sugar into his cup.

"Still," Assetan persisted after a long pause, beginning to shred the leaves into long slivers.

"Women must be circumcised chez nous. You must agree with that. Even if it is not what you do in your country, then you must agree that it is right for us." She looked anxious and I did not know exactly what to say. I wondered how to tell her that I did not agree but that I respect her and her culture. I could not figure out how to make my answer balance how I felt with how she felt.

I thought for a long time about this conversation and what I perceived as an ethical conundrum with what I did with this in terms of my own research, how Adam had been so central to the dialogue, and also how the Coulibalys and I would continue to live together. Assetan distanced herself from me after our conversation and it took several weeks before we spoke of anything beyond food and washing our clothes. The fracture of feelings about what was morally right and what was culturally right characterized the questions I had of how and whether to implement human rights laws whose moral discourse did not match with all cultural ones-even for an anthropologist questioning the culture concept.

I had been hailed by the name "Kadja," a perlocutionary act that I felt summoned me into a new subject position where I had to navigate new customs, laws, ethics, and ways of communication (Austin 1975). I came to respond to Kadja and forgot about "Ruth." That other self existed in a different world at a different time. I was that person and not. I had become the Other's other. I was both Ruth and Kadja for the girls. Polysemically, I came to inhabit different identities while remaining in the same body.

\section{Bodies as Sites for Knowledge Production and the Construction/Location of Self}

The category of the person and the concept of "the human," and the relationship to the body within the discourse on FGC leads me to the question of where "the self" or femalehood is located in the body, if there at all. It also begs the question of why the West focuses so determinedly on FGC. Elizabeth Povinelli writes of the liberal concept of multiculturalism in 
the West as finding "exemplary expression at the tip of the clitoris" (Povinelli 2002: 26) and of the kinds of life and lives worth saving within a liberal paradigm.

Povinelli does not espouse a sliding scale of ethics, but rather wants to consider how difference-in cultural practices and in what constitutes the human-gets recognized and by whom. Malians who agreed or disagreed with the FGC routinely punched the questions back to me in what amounted to a synthesized slew of words: "Human rights? What are human rights? Who is human? Us? How can you Americans kill people with your government and call other people barbarians? How can you call your government a humane one?

I could not offer a satisfactory answer, not to myself nor to my Malian friends. The gift of turning a critical eye to how human rights recognizes the difference between what constitutes humane and inhumane practices was one I could not reciprocate. I did not feel that my place could be anything other than to offer another way of perceiving, living, and recognizing the female body. I could not tell them what to do. I had to wonder how did or had the neoliberal environment in which I lived and grown up and into dictate the kinds of life(styles) I saw and valued? Povinelli asks her readers to develop a "critical theory of recognition" (Povinelli 2002: 17) so as to better understand the cunning involved in the conflation of politics of culture with the culture of capital. The practice of capital punishment in some Western countries juxtaposed with the practice of female circumcision in Mali illuminates the "rational" inconsistencies in both. Would FGC, along with abortion, have become so important to eliminate in the colonies if it had not contributed to a perceived decrease in labor (re)production?

Janice Boddy argues along this theme of reproduction and labor-both in terms of human bodies and in terms of commodities. She explains the irony of British efforts in Sudan to eradicate the practice of some kinds of female circumcision during the first part of the twentieth century, primarily infibulation - the pharoanic form of cutting. Pharoanic circumcision entails cutting the clitoris, the labia, and sewing the whole area shut so as to keep it smooth and without any hint of protrusion, all performed without anesthetic. The final result should be one where the female body looks nothing like the male body. The British efforts to end what continues to be considered by health and humanitarian organizations the most harmful cutting practice ultimately led to a further entrenchment of the practice (Boddy 2003). In Mali, the French encountered a similar dénouement.

Framed as "humanitarian and civilizing" in colonial semiotics meant that Britain was losing its hold on international trade (Boddy 2003: 61). While economic and political aspirations must certainly have played a part in the eradication efforts, to reduce the British efforts to theories of political economy erases the heteroglossia and multiplicity of intentions that we anthropologists seek to recognize, or at least, illuminate. Theories of a political economy of the body also devalue internal thoughts and sentiments and place the category of the person in a network of intercalations of value and exchange where agency plays no part. Did health care workers and teachers truly go to remote villages, suffer the severe shiverings of malaria, and live far from their birthplace simply for the glory and treasury of Britain? Solely an economic explanation cannot account for the infatuation with infibulation. For anthropologists, theorists, or policy-makers to elevate the external world risks doing away 
completely with agency. Yet to elevate the internal world risks the hubristic charge that someone can see another person's internal world better than they can. Perspective makes, as well as accounts for, the cunning of difference.

The World Health Organization (WHO) has been working on the eradication of FGC, which has considered FGC a human rights violation since 1997. The organization estimates that between 100 to 140 million women and girls have underdone the procedure. ${ }^{8}$ The procedure, however, is by no means uniform around the world. WHO designates four kinds of female circumcision ${ }^{9}$ :

1) Infibulation-Infibulation almost entirely seals the vaginal orifice, leaving a small opening by cutting and then repositioning the inner, and often outer, labia. The clitoris may or may not remain intact.

2) Excision-Excision leaves the vaginal orifice open but involves eliminating some or all of the clitoris and the labia minora. The labia majora may or may not remain intact.

3) Clitoridectomy-Clitoridectomy involves a portion or complete elimination of the clitoris. The prepuce (the fold of skin surrounding the clitoris) may also be removed. The labia remain intact.

4) Other-Any action that damages the female genitalia

I want to underline that even while touting the numbers produced by the WHO and other international agencies, these statistics that are just that, produced. Knowledge of what FGM or FGC means has come to the West via anthropologists, missionaries, and public health workers (often the lines between the three are/were not so rigid). In the last decade African voices have grown stronger both for and against the practice of FGC, most of them musicians of international renown. A 2000 an album entitled "STOP! Excision" featuring top Malian male and female artists, among them pop-stars Amy Koita and Kandia Kouyate, came out against FGC and other forms of violence against women.

Amy Koita (a woman) sings "O Magni" - "It is Bad."

Let's do what's good. Let's not do what isn't good.

Ever since the beginning of time it's been normal and acceptable to circumcise men.

That's good. Let's keep doing it. But excision of women has never been an obligation.

O kagni an ka o kè. O kagni o bè ben. O magni an ka na o kè. O magni o tè ben. Kabiri dunya dan n'a, cémani ka sigi yè wajibi yé! Kabiri dunya dan n'a, musomani ka sigi tè wajibi yé!

There are African countries which don't excise because they prioritize their health. Excision gives us problems in childbirth, troubles in married life, health problems. 
It can even kill people.

Farafin dugulu yé yen, o lu rè sigila negé koro. O sababuya yé min di, olu yé keneya de ko. Ni I sigira kèné la, a yé I ka bange le geleya la. Ni I sigira kèné la, a yé I ka furuso le geleya la. Ni I sigira kèné la a yé I ka keneya ro tinyè la. Ni I sigira kèné la a yé I ka dinyèrotegè be tinyè la.

Let's not do what's bad. Let's do what's good.

O kagni an ka o kè. O kagni o bè ben. O magni an ka na o kè. O magni o tè ben.

Africans have spoken. Television has spoken. The radio has spoken.

The media have spoken. Doctors have spoken.

Everyone says that excision isn't an obligation for women.

It's not good. Let's not do it. It's not good. Let's not do it (STOP excision CD)

Africanou kumana. Televisionu kumana. Aradiosolu kumana. Dokotorolu kumana.

Presilu kumana. Conferencilu ké ra. Olu bè farala nyogou kan ku sigi ka kuma, musomani ka sigi tè wajibidi (Diawara 2009).

Musicians hold significant sway in Mali, their voices ring through neighborhoods from the radio, the T.V., from the live body. Their words are sung and repeated at soccer games, on the way to the market, while carrying water. In the checks and balances of power they enjoy their elevated social status while also being the target of jokes and derision on their mobile lifestyle, not grounded in growing food from the earth.

What is striking about Amy Koita's lyrics are that the nation, "Africans," the television and the radio - the media have spoken first, then the doctors. The doctors hold, in many ways, a less advanced social status than the musicians. The role of biomedical experts has less airtime than that of the nation's performers.

Kandia Kouyaté sings Let's Decide To say "NO" (An Ka Fo "Ante”) to a rhythm called "bajaru," a popular tune for women's songs. ${ }^{10}$

Oh, Mother! Oh Father! This woman has a knife, the knife of excision.

I don't want to get near her.

N'na wo n'fa, nègè bè mogo mun bolo, bolokoli muru

N'tè gèrè o là, n'na wo!

It's hard to make it rain. It is hard to control the heat.

We can't avoid lots of bad things. But we can avoid a lot of pain.

Sanji! wèlé li ka gèlen. Funteni! Kèlé li ka gèlen.

An ti sé ka fen caman bali. An be sé ka dimi caman kèlé!

If we stop excising our daughters, this would make girls' lives easier, and no more girls will die for no reason. 
Jama an ka n'gani kè siri ka muso ka nègé kòró sigi da bila; o ka kè sababu yé ka dusu suma sé anw musow m'a, o la denu te'na fato gan san!

Don't our bodies belong to us?

Women's bodies hide many marvels. So don't hurt them.

Nothing is gained by hurting us. So let's say "No, we refuse! We refuse!"

Nègè ka tigè li bè na ni kènè karabali ye, ni Allah ma fara I kan a b'è I son sida la. An ka fo ko "ante!" An ka fo ko “ante!"

It is hard to follow the lyrics and couplets to their origin. How did Amy Koita and Kandia Kouyate come to these words and conclusions? Had they always felt this way or had they been influenced by their travels around the world and contact with women's health organizations?

Oumou Sangare, another female musician of international fame has toured the world and sung against such issues as polygamy, forced marriage, and had promised songs about excision. Her perspective on marriage has been more powerful because she has not always thought that way. She had also been a proponent of "excision" and only after listening to women's stories did she decide to make the practice one that she would seek to end. In a series of interviews from 2000-2003 she spoke out against female circumcision ${ }^{11}$. She has not, however, released an album or even a song against excision and given the present political climate, is not likely to do so.

In September 2009, Malian president Amadou Toumani Touré refused to sign legislation that the National Assembly had passed in late July called "Le code des personnes de la famille" (The code of the people of the family) that was dubbed "The Women's Law" because it gave women the right to disobey their husbands, strengthened the inheritance laws for children born out of wedlock and made moves toward eradicating excision. Bamako erupted as both women and men took to the streets, protesting the disregard for Muslim law. Newspaper articles and editorials slammed the law and the national assembly for its capitulation to "intellectuals" to sociologists, anthropologists, and philosophers who promulgated the law of the family and its "disuse" 12 .

Malian musicians have not stepped forward to promote the law. While intelligent, they are not considered "intellectuals," and would have more impact than, say, the sociologists, anthropologists and philosophers who have become the target of animosity. They risk, however, not simply losing pop-star status, but also the peril of physical acts of reprisal.

Not all African intellectuals fight against FGC. Sierra Leonian Faumbai Ahmadu spoke to the American Anthropological Association in 1998, shocking audiences by challenging the categorization of female circumcision as a human rights violation (Shweder 2000). She described her own personal success story as a circumcised woman to illustrate how she felt that humanitarian aid workers, scholars, and government officials had misunderstood, misinterpreted, and misrepresented FGC as a ritual coming-of-age practices. 
Harvard Medical Anthropologist and Epidemiologist Carla Obermeyer also voices an opinion that goes against the sheer and certain brutality of female circumcision. Obermeyer analyzed studies of FGC published between 1997-2005 and concluded that the slew of health disorders adamantly associated with the set of cutting practices had a shaky empirical base. Going through the literature, she found that any effort to statistically calibrate the extent to which the female body had suffered damage from infibulation proved difficult and the results ultimately unsatisfactory according to Western standards of scientific research (Obermeyer 1999, 2005).

Obermeyer did not refute the idea or the evidence that FGC can cause certain gynaecological infections but she challenged the certitude on which humanitarian agencies founded their efforts and the empirical data employed by anthropologists. Not all types of female circumcision caused the physical harm that had come to be synonymous with the three-letter acronym. Obermeyer underscored "the need to go beyond simple inventories of physical harm or frequencies of sexual acts" (Obermeyer 2005: 456). Obermeyer also focused on the sexual effects arguing that she found no supporting evidence that circumcision meant that women could not experience enjoyment.

While Obermeyer's analysis makes the important point that anthropological methodology had made the errors of building on hypothesis taken as and manufactured into fact, she also made choices to include and exclude certain kinds of information to support her claims. The value of her study is that any method of the social sciences (and of medicine) will have its flaws and that the politics of representation play a main role in how and who creates knowledge and how and who circulates such knowledge. There is evidence that FGC can permanently damage a woman, but if such criticisms come from the liberal multicultural front, then they must rely on sound evidence-and from women who have undergone circumcision. The question becomes how to reconcile the perspectives of Ahmadu, the Sierra Leonian anthropologist, and Koite and Sangare, the Malian songstresses-of one woman who feels empowered and two women who feel disempowered and disenchanted by the practice of FGC. Where these women find themselves in the debate and in their bodies, both circumcised (though we do not know to what degrees) may or may not be different. With or without all of their differentiating anatomy, both recognize themselves as a woman, as did Assetan, Miriam, Fanta and Poupée-my host sisters.

Ahmadu spoke as an anthropologist, Koita and Kouyaté sang as international stars, and my host sisters spoke to me as a family member and as a friend, raising the question of voice-of who has a right to speak for whom, how, and why. This question of voice weighed and weighs on me. How and whether I should to write and share further the conversations that I had with my host sisters either as ethnography or as public health information. Ethnographic writing can also be an intervention with political consequences that are not always good. Good often has a spectrum of relational meanings and manifestations in the world. Various NGOs use such ethnographic data to design and improve health and humanitarian programs. What represents "the truth" differs, as Obermeyer, Ahmadu, Koita, Kouyaté and even Sangare (for her silence) illustrate, for different people. One does not have to agree with their findings and conclusions to agree that they represent dissenting voices in the debates surrounding female circumcision and its eradication. It becomes difficult to look critically and to argue 
with an ethnography and with organizations that don the dress of human rights, cloaked in the speech of liberty, because what is at stake is human life.

I found myself, as I often do, at the ethnographic and very human interstices of having to decide how I see difference. I agree with the honoring other people's beliefs. This does not necessitate a blithe acceptance or condoning of FGC. Nor does disagreeing with or questioning universal human rights laws mean uncritical acceptance of all differences. It does mean, however, acknowledging that universal human rights has the potential to be used for the same kinds of social, economic, and political control as, say, female excision.

\section{Ethical Language, Life, Lexis, and Logos-Mapping the Human}

Who speaks, who has a right to speak, and whose voice gets heard becomes a central question in a country that just voted down legislation that would have given women the right to not obey their husbands ${ }^{13}$. When the president vetoed the law, he effectively killed the revolutionary legal opportunities and protection for women. Among the changes for women was the right to "say no" to excision ${ }^{14}$. Women, not just men, had taken to the streets to protest the law, mainly if not entirely those who adhered to a more strict practice of IslamWahhabi. As Saudi money and NGOs have increased their presence in Mali, so has the Wahhabi insistence on a total return to the Qur' an and hadith in conjunction with a rejection of animism. The charge that intellectuals were behind this, not just foreign ones, but Malians too, brought up the insider/outsider conflict that occurs so often in discussions of rights.

Often the charge against organizations geared towards social change is that they should let the people decide and speak for themselves. In the case of FGC and the Law of the Family, that the women should decide "on their own terms" without "outside influence." If women have no political voice, however, but seek it, then the "hand's off" approach becomes more complicated. Who counts as a full person in front of the law, as a self-sovereign enlightened subject with a voice depends on who is doing the boundary-work-both of the physical and of the social geography. It comes down to how differences-between male and female, humane and inhumane practices, and the human and nonhuman — are seen to manifest in the world.

How anthropologists perceive and conceive of difference greatly influences the practice (methodology) of naming what constitutes a human being. It can also influence whether or not they think that anthropology does or should have a voice in human rights issues. The same goes for those making laws and policies. The perception of difference also impacts the acknowledgment of who speaks and of who is worth listening to-where we draw boundaries depends on the terrain itself. It also depends on what we see, visualize, and make intelligible and perhaps thus interpretable and interpellatible. Like poems, the talking drums and dancing are sites of knowledge production "where language is an actor independent of intentions and authors, bodies as objects of knowledge are material-semiotic generative nodes. Their boundaries materialize in social interaction" (Haraway 1991:185). What becomes a body, a "matter of fact," or a human rights violation and what does not, depends on how boundaries separate and connect such categories.

Difference that connects has positive overtones while difference that irrevocably divides comes off as bad. What is human(e) and inhuman(e) has shifted categorically speaking, and 
anthropologists have always taken a special interest in classification. So is female genital cutting a cultural difference that is bad because it slices through our moral values and divides the woman from her body? For the cultural relativists, differences should be honored and the anthropologist should not judge nor interfere. Balinese cockfights aside, what kind of ethical responsibilities are involved when thick description describes an event like a circumcision ceremony or a birth?

Melissa Parker conducted field research in Sudan on schistosomiasos but ended up witnessing multiple female circumcisions that caused her to think about her place in the community of Omdurman aj Jadida both as woman and as anthropologist. She struggled to congratulate the mothers whose daughters she had watched undergo circumcision while appreciating other ways in which the women approached their lives. "On the other hand," she writes that witnessing the circumcisions caused her such distress that she avoided investigating the practice in any other way, diving instead into her research on schistosomiasis. The sense of relativism with which she approached her work "also became a means by which to avoid addressing a difficult and conflict-ridden area" (Parker 1995: 512). She defines her stance on participant observation as not necessarily requiring identification "with every aspect of life in her community; or to put it another way, understanding does not preclude judgment (ibid). Parker both avoided and participated in events that troubled her, but what ultimately became the most disturbing occurrence was the prevalence with which she encountered friends and colleagues condemned FGC without inquiring into the cultural beliefs surrounding the practice. They condemned the bodily practice as barbaric and inhumane, habits and beliefs of "simple and uncivilized people" (ibid: 513).

\section{Habit(u)s, Beliefs, Practices}

Marcel Mauss' "category of the person" from his piece "Techniques of the Body" illuminates habits, beliefs, and different ways of perceiving the body. Mauss wrote that different perspectives informed the characterization of the category of the person, which changed with time and place. He saw a trinity of relations that made the 'total man' - the psychological, the biological, and the social or educational. The "internal" (or the psychological/biological) and the "external" (the social/educational) interactions occurred at and within the body. Mauss characterized these interactions as manifesting in the techniques of the body, as "the ways in which, in different societies, men know how to use their bodies" (Mauss 1973: 70). Every society has its own specific habits. People come to embody these habits, aspects of their culture, and categories of social definition (personhood) through inherited and practiced social acquisition. For Mauss, every society has its own specific bodily habits. The human, on the individual and collective level, seeks and gains definition and identity through such habits.

Upon the Maussian "techniques of the body," Bourdieu expands and expounds the notion of habitus. In "Pascalian Meditations," he examines subject formation and constitution in practical action through an analysis of a person's embodied position and bodily knowledge within social and physical space. He does not engage in differences of gender, nor did Mauss. Here, the non-gendered "I" that "comprehends physical space and social space...is not necessarily a 'subject' in the sense of philosophies of the mind, but rather a 'habitus', a system of disposition... is comprehended...encompassed, inscribed, implicated in that space" (Bourdieu 1997: 130). The embodied self gains identity through social interactions. A 
system of dispositions results from "corporeal knowledge" and a practical comprehension of the world, while it also creates the external limits to the individual's world, structuring the social field. "The function of the habitus restores to the agent the generating, classifying, constructing power to construct social reality, that itself is constructed by the social (Bourdieu 1997: 136).

How agency exists, if at all for Bourdieu, has salience for social scientists that work in the service of humanitarian organizations. How do Malian women have agency or choice when it comes to participating or not in FGC if their habitus predisposes them or demands that they partake in a social ritual? Or if they lack the political voice with which to be heard and effect change?

Bourdieu writes that: "The social order inscribes itself in bodies.... The most serious social injunctions are addressed not to the intellect but to the body, treated as a 'memory pad'. The essential part of learning of masculinity and femininity tends to inscribe the difference between the sexes in bodies." Various institutions work to write these social distinctionsmale/female - through bodily practices such as walking, standing, the wearing of certain clothing. All these mark the gendered human body that participates in the social body. "As much in everyday pedagogic action ('sit up straight', 'hold your knife in your right hand') as in rites of institution, this psychosomatic action is often exerted through emotion and suffering, psychological or even physical, particularly the pain inflicted when applying distinctive signs - mutilations, scarification or tattoos - to the surface of the body itself" (Bourdieu 1997: 141).

Separating the discourse of female circumcision from my first and continuing impression of Malian women as strong, authoritative, and often back-talking does not help to place the category of the person. FGC has existed longer than human rights activists had thought, stretching perhaps back to the time of the pharaohs. "Modern" Malian women zoomed around the city on mopeds, zipping in front of and around men. They danced to teach, learn, and enjoy sexual relationships. The cutting of the clitoris seemed to do nothing to change a women's natural desire to be loved and admired. Neither did the cutting of the clitoris seem to diminish prostitution. Prostitutes do not necessarily sell sex because they like having it.

For human rights activists fighting FGC, the practice has proven stubbornly rooted in human bodies and minds as well as in the body politic. Embedded as it is in a cultural history that includes a colonial presence, female circumcision does not gracefully leave through the bureaucratic or social backdoor. ASDAP, the Malian NGO that I came to work the most closely with-Association de Soutien au Développement des Activités de Population or Association of Support for the Development of Population Activities-sought to work through FGC in a bodily way. I worked often with Dr. Traore, a young good-looking doctor that made the young women giggle when they came to see him. In his quiet and professional way he would explain each movement of his exam and make sure that the women left feeling better than they came. When I asked him about excision, he looked at me blankly. "Culture, c'est pas une excuse pour abuse." 
"Culture is not an excuse for abuse" has echoes with human rights rhetoric expounded by Western NGOs, but Dr. Traore meant it from his own experience. The clinic was an education center for youth as well, which helped hide women that were going for family planning reasons, either against or unbeknownst to their husbands. Upon leaving such clinics, women would be harassed or beaten. ASDAP had thus far managed to keep its clientele safe. The organization housed a clinic whose three doctors served both women and men, along with fifteen peer educators who fanned out through Bamako and its environs. The peer educators' dancing and drumming activities along with playing soccer, helped "work out" questions about sexual practices.

At ASDAP, I ultimately became the be-all apprentice. I assisted the doctors and midwives with exams, played with children in the waiting room or garden grounds, and went with the "peer educators" into the field, literally, the soccer field. During practices or at halftime we would talk about sex. Word spread quickly throughout the neighborhoods about our special games. Young boys and girls who wanted to ask questions or simply to listen would come together twice a week in the afternoons. We kept the utmost privacy. Players and doctors would tell me about women attacked by neighbors when going to the clinic for pregnancy exams at ASDAP. I had worried that my presence would be more a hindrance than a help, drawing unwanted attention to the organization. Thankfully, this turned out to be otherwise. It was easy to laugh at the toubab (white person) chasing after the much faster Malian teenagers. It was also, fortunate or unfortunate, an honor to have a toubab assisting at the clinic. My presence either meant entertainment or elevated status.

On the soccer field, Malian youth between the ages of 10 and 16 gathered. The girls who played soccer (and it was exciting that they did come out and play) were usually on the younger side. Family obligations, like marriage or caring for the family often demanded their time more than it did the boys.

"So you work mainly with boys, then?" I asked Fanta, a peer educator who never played but would watch and act as "coach" for the various sex-education teams.

"On the field, yes, but you know, lots of girls come to watch, and I can talk to them while the boys play."

"And the boys, they don't mind talking about female issues?"

"No, they usually ask more about the women than they do about the men! This is the only way to reach them."

As with my host sisters, the lack of male participation came up again and again. The assertion that men had "nothing to do with it" contradicted the idea of FGC as male oppression.

However, it could be that Bourdieu's notion of habitus underlay the apparent lack because the practice had becomes so ingrained in the social body that there was no need for men to exert socio-political control. Given the recent events concerning the law of the family, this may and may not be the case. Malian women took to the streets to uphold the shariya law, so one could argue they were so inculcated with the socio-cultural beliefs and habits as to be unable 
to see any other way of being in the world. Yet it was ultimately a male president who shut down expanded rights for women.

In trying to understand other ways of being in the world, what are the ethical obligations to tell a culturally relative story? At what point can or does an ethnographer decide that the body, as a thickly cathected site of socio-cultural, political, and economic factors is part of the moral economy of the self has a limit to its modifications? ${ }^{15}$ At what point does cultural relativism deposit the ethnographer at the limit of his or her distinction of humane and inhumane? At what point does it become unethical to fail to distinguish between the two?

\section{Ethical obligations?}

In ruminating upon these questions, Paul Farmer, who uses a "historically deep, geographically wide" approach to human conditions of suffering, comes to mind. He sees everyday violence as taking more victims than natural disasters or even wars. Everyday structural violence ranges from the colonial lines of power drawn so many years ago and have become naturalized into the social landscape so that people do not notice how violent inequalities are socially constructed and culturally maintained. For Farmer, the "habitus," those dispositions and conditions like endemic poverty and disease, are structured from a colonial past. They continue to structure the violence that Haitians live every day, unable to gain access to health care that could or would save their lives (Farmer 2004). The alleviation of blame and responsibility plays an important part in Farmer's ethnographies, redirecting social and physical ills back to a colonial past.

Nancy Scheper-Hughes also highlights the structural violence that she sees occurring. For her it happens everyday in Brazil. What she perceived as a lack of negative reaction on the part of poor mothers who lost infants, led her to look at the socio-economic relationships that "normalize" infant mortality for poor women and thus produce "a state of indifference about life and death" (Scheper-Hughes 1992: 276). Her socially wide and emotionally deep approach reveals a network of social relationships that range from class hierarchies, access to health care and information, geographic location outside of popular public health care circuits.

Scheper-Hughes concludes that because these women have no recourse to save their children's lives, their reactions are reflective of the broader social context in which they live. The emphasis on the need to be seen as "modern" Brazil resonates with a desire to not be seen as "backward" in Mali. In Brazil, Scheper-Hughes views modernizing Brazilian society as intentionally misrecognizing or misdiagnosing the reasons for infant mortality. For Malians, often the stigma of being a "poor" and "backward" country smacks with "traditional." Thus, recognizing "traditional" forms of bodily practices such as circumcision as contributing to or directly causing infant and maternal fatality would be an admission of inferiority. As the Brazilian doctor speaking to Scheper-Hughes said, it is "the social embarrassment and the bureaucratic indifference toward child mortality as a premodern plague in a self-consciously modernizing interior town" (Ibid) that keeps hinders human rights programs initiated by Western humanitarian organizations. The opposition of modern vs. pre-modern (traditional) leads to destructive forms of social reproduction and biological reproduction, of social or biological death (Biehl 2005). 
The application of structural violence as a lens and as an explanation has it benefits and its drawbacks. It can, depending on the interpretation, easily become a patronizing and disempowering analytical lens. So what is the ethical obligation of the ethnographer? To write but not judge, to judge but not act?

Paul Rabinow asks how 'ethical relations' became a zone of obligation with such charged importance, particularly in the realm of genetics and health. Some anthropologists has constituted and pursued "ethics" as an object of inquiry and embedded it as necessary to the thought process (Rabinow 2002). His line of questioning juxtaposes with Povinelli's observation that the liberal multicultural imaginary produces the vision that certain kinds of violence appear accidental to the system rather than generated by it (Povinelli 2005). Rabinow's critique of human rights discourse encompasses both on this naturalization of certain kinds of violence - who gets to "let live" and who gets to speak. He asks how human rights discourse relates to issues of health and then how health and rights relate to biopolitics. Market cultures and religious cultures help to define "who speaks morally, how to speak morally, and what moral speaking is about" (Rabinow 141). It is these questions of voice that also define Povinelli's multicultural ethics.

Michel Foucault, Rabinow's mentor, defines ethics along Aristotelian lines, as "objective selffashioning" or "arts of the self." Foucault defines ethics as "techniques of living" and improving one's self. Language as it is spoken, heard, thought, and written plays the main part, but so does a kind of body language. Logos refers to speech and reason, but there is also lexis, a way of saying things. Philosophical logos cannot exist without lexis, "this kind of body language with its own qualities, its own figures, and its own necessary effects at the level of pathos" (Foucault 2005: 368).

Paul Rabinow writes that Foucault viewed his task as a thinker to liberate possible ways of thinking that lie beneath the radar of language. The very act of thinking is a vehicle for transforming the "constative to the subjunctive, from the singular to the multiple, from the potential to the virtual (Rabinow 2002: 139). He follows Dewey who places thinking and reason in a "mi-lieu" and assigns it a mediating function between two opposing positions. Thinking then yields intervention, tailored to the needs of the situation. Rabinow disputes the anthropomorphism of a "situation" and critiques discourse on human rights and the construction of the human as an object of inquiry that is subject to intervention. "Don" in Bambara, then, became for me not simply a way to mediate between two realms but to connect and move between and betwixt them. The kind of body language, the lexis, became not just important to communicate but also to live.

Charles Briggs writes about "cartographies of communicability" drawing on a notion coined and explicated by Veena Das about how discourse travels. Briggs defines "communicability" as the discursive landscape that becomes visible and emerges from a Bourdieuvian network of social relations. This social field organizes and produces particular social positions and relations while reading like a map, designing the contours of communication channels. Such cartographies create subject positions "that confer different degrees of access, agency, and power, recruit people to fill them, and structure practices of self-making within their respective fields" (Briggs 2007: 333). The ability to be both like a woman for the Coulibaly 
girls, but not one of them, placed all of us in new positions vis-à-vis one another, but also visà-vis a newly formed knowledge that called upon us to think, know, dance, and for me, to find my voice differently.

Often the anthropologist finds herself in a position of knowing the people and the issues of international humanitarian concern on the ground better than the policy-makers and implementers in the office. With that knowledge comes complicated ethical questions of the role of the anthropologist and the commitment to larger human rights projects and to people who no longer represent informants but who have instead become friends. Although Foucault invoked the word "ethics" differently, the very use of the words "ethics" or "ethical" tends to have moral connotations, particularly when talking about human suffering. Das has focused her work on the violence, often directed at women and criticizes anthropology as a discipline for not developing a foundation of knowledge for "anthropological ethics." Such ethics would guide the anthropologist in understanding acts of violence (Das 1985:1) rather than perpetuate by recounting and exoticizing them in narrative.

The American Anthropological Association's (AAA) code of ethics clearly does not encompass a wide enough range of guidelines for Das. The preamble opens with that statement that:

"Anthropological researchers, teachers and practitioners are members of many different communities, each with its own moral rules or codes of ethics. Anthropologists have moral obligations as members of other groups, such as the family, religion, and community, as well as the profession. They also have obligations to the scholarly discipline, to the wider society and culture, and to the human species, other species, and the environment. Furthermore, fieldworkers may develop close relationships with persons or animals with whom they work, generating an additional level of ethical considerations" (I. Preamble: Code of Ethics of the American Anthropological Association).

Das writes that the "task of conceptualizing violence is difficult" (Das 1987: 11) in response to the three days of violence and killings against Sikhs that followed Indira Ghandi's assassination by Sikh bodyguards and that the "greatest difficulty of studying a situation such as this is that the anthropologist cannot remain uninvolved" (Das 1985: 6). How does the anthropologist not become involved politically and/or emotionally when faced with such immediate and culturally entrenched violence? Her commitment to activism and refusal to standby and merely document led her to take action as she saw ethically fit. Women had been raped, left for dead, or risked death upon returning home. For Das, the theories of political economy cannot fully explain the turns to violence. With the task of conceptualizing or classifying the violence of FGC, also culturally and historically entrenched, comes the question of how remain uninvolved. The ethics of staying quiet seem equally as heavy as the politics of speaking out.

Das takes up suffering again, as well as identity in "Voice as Birth of Culture" and "The Language and Body: Transactions in the Construction of Pain." In the former she explores the fate of Sophocles' Antigone who dies at the hands of her uncle Creon, his hands and reputation extended through and kept clean by state mandate. She chose to bury her brother 
who had tried to reclaim the role of ruler after the suspect death of their father. Deemed a traitor for trying to take power from their uncle, his body was left outside the walls of the city for the birds. The punishment for Antigone's crime is to be buried alive. Das comments that when "a person can bear witness to this form of suffering through the act of hearing, when the eye becomes transformed from the organ that sees to one that weeps, that we can speak of culture as having developed a soul" (Das 1995: 162). She is also asking about what could happen when an anthropologist can bear witness to suffering, when the eye, ear, and hand work in tandem to see, listen, and write differently about ethnography. The question of voice, not simply spoken but written carries weight. We tell a story, but sometimes language does not suffice and the task of story can become freeing "the self that has become frozen in language" (Das 1997: 71).

For Das language is tied to the body, whether voiced from the vocal cords or marked corporeally. She focuses less on the network of social relations-habitus - and its dispositions, and more on the individual stories and the present moment. The present moment, of course, like the past, can infect and affect the future, but Das writes with what I perceive as hope, "that individual lives are defined by context, but they are also generative of new contexts" (Das 2000: 210). The category of the person lives on, generating new ways of being-in-the-world.

\section{Concluding (But Not Precluding) Thoughts}

Before I arrived in Mali, someone had asked me what I would do if Malians told me that circumcision must continue. I did not know then and my answer is complicated now. What I do know is that the Malians with whom I worked at ASDAP explained their position to me in one sentence: "Culture is not an excuse for abuse." I did not agree with FGC, but I did not know how someone, or some organization, could extricate such an entrenched practice without upsetting socio-cultural identities and integrity. After my conversation with my host sisters, I realized how individual and collective cultural "self" and dignity were also at stake. I also realized how my sense of self came into being dialogically with my "informants.

My conversation with my Malian sisters opened up new conversations between us. Stories we told one another elicited more stories. Story became the method of research, stories told through the dances, through the drums, through the football-playing, and through interactions over everyday activities. Our intercultural dialogue was about the possibilities of having such dialogues. Could we find a common ground? Could we speak and be heard in the way we wanted to be known? The complexities of FGC did not diminish; rather, I came to see them more clearly. Reflecting on oneself and questioning one's elders and ancestors is a painful process. Assetan continued asking me about how women lived in France and the United States, questioning her own practices by critiquing those of the toubabou.

The USAID workers with whom I had first made contact, kept in touch with me. They asked for reports and field notes, or any findings that would help them improve the transmission and reception of public health information. They were surprised to hear that even in my middleclass Malian family, with ten children in school and fluent in French, that they could not read or understand the USAID sponsored billboards about using condoms, about HIV/AIDS risks, 
or the "right" to say NO to sex. It was difficult for me not to question the nature of public health intervention, the humanistic intentions behind it and the possibility of unforeseen and unwanted consequences. In a similar, but I emphasize, not in an equivocal way, I, like Assetan, was questioning my cultural lineage and ways of being, participating, and interacting in the world.

I do not want to seem as if I oppose humanitarian efforts. I ultimately disagree with the practice and execution of FGC, but I want to show how complicated and embedded a practice it is, not easily extricated - certainly not by the billboards, pamphlets (that often found their way into the loo for use as ineffectual and uncomfortable toilet paper), and power point presentations. Malians with whom I spoke did not see the billboards as anything more than ornamental, nor did they have time to go to the sponsored power point sessions. They did, however, have time for family, festivals, and football. I enjoyed doing my research but I continue to struggle with the ethics of analyzing someone else's social practices, representing them, and thus wonder about sharing or using ethnographic data-interviews and participant observation - for development and humanitarian aid organizations. Such organizations can be themselves political regimes, even if their intentions are benevolent. Knowing where or to whom anthropological work goes can dictate or occlude — not just preclude — certain ways of being, seeing, speaking and writing-in-the-world. If ethnography is itself an intervention, how anthropologists research, not just what they write afterwards, has consequences.

Thus, studying the different ways of speaking and knowing, of who is speaking and who knows, has been and continues to be my focus. I have not finished working through my experiences in Mali but anthropological "thinking" helps me give shape to experience and form to content. I conclude along the lines of Bettina Shell-Duncan who advocates for a deliberate and thoughtful approach towards FGC. What exactly that might mean is not entirely clear. It might mean that only the most-invasive kind of excision constitutes a human rights violation. It might mean negotiation and instantiation of myriad socio-political views to reach international consensus. As Shell-Duncan writes, "we need to remind ourselves again that this is a social issue that reaches beyond its political ramifications. As such, viewing protection from FGC as a right to be enforced, granted, recognized, and implemented by the state must not de-emphasize or delegitimize approaches recognizing the cultural significance of FGC and the potentially multiple and cascading social effects of ending the practice" (Shell-Duncan: 230). To accomplish such a feat necessitates moving beyond traditional methodologies and listening to the voices not often heard. It may mean policing and questioning the motivations behind universal human rights reforms. It will mean looking at, listening to, and understanding the body and its language in different ways.

Language, in verbal or textual form, as spoken through the body or through the talking drums, invites me to learn of the multi-valence of communication. It allows me to characterize the process of creating an object of inquiry, rather than creating an object's content by fixing dynamic life. The cartography of communicating such thoughts and experiences continues to provoke for me the question about whether some truths might circulate or come to be better known when (un)spoken. Learning about the different ways of listening, being, seeing, and writing about the world to the beat of the talking drums brings with it ethical ethnographic conundrums, but ones worth exploring and expanding upon. 


\section{References}

Ahmadu, F. 2000. Rites and Wrongs: An Insider/Outsider Reflects on Power and Excision. In Female "Circumcision" in Africa: Culture, Controversy and Change. Shell-Duncan, B and Ylva Hernlund (eds). Boulder, CO: Lynne Rienner Publishers, Inc.

Aristotle. 1984. The Politics. Translated and with an introduction by Carnes Lord. Chicago: University of Chicago Press.

Austin, J.L. 1975. How To Do Things With Words. Boston: Harvard University Press.

Bâ, A. 1972. Aspects de la Civilisation Africaine. Paris: Présence Africaine.

Biehl, J. 2005. Vita: Life in a Zone of Social Abandonment. Berkeley: University of California Press.

Boddy, J. 2003. Barbaric Custom and Colonial Science: Teaching the Female Body in AngloEgyptian Sudan. In Illness and Irony: On the Ambiguity of Suffering in Culture. Lambek, Michael and Paul Antze (eds). 2004. New York: Bergham, p. 60-81.

Bourdieu, P. 1997. "Bodily knowledge" from Pascalian Meditations. Translated by Richard Nice. Stanford: Stanford University Press.

Briggs, C. 1986. Learning How to Ask: A sociolinguistics appraisal of the role of the interview in social science research. Cambridge: Cambridge University Press.

2007. Theorizing Relations between Narrative and Violence. Cultural Anthropology 22(3):315--356.

Diawara, B. 2009. Translations of Amy Koita's It's Bad (O Magni) and Kandia Kouyatè's Let's Decide To say 'NO" (An Ka Fo "Ante").

Das, V. 1985. Anthropological Knowledge and Collective Violence. Anthropology Today $1(3): 4-6$. 3(4):11-13.

1987. The Act of Witnessing and the Speech of Victims. Anthropology Today

1995. Voice as the Birth of Culture. Ethnos 60(3-4):159-179.

1997. Body and Language: Transactions in the Construction of Pain. In Social Suffering. Kleinman, A, Das, V and Margaret Locke (eds). Berkeley: University Press, pp. 67-91.

2000. The Act of Witnessing: Violence, Poisonous Knowledge, and Subjectivity. In Violence and Subjectivity. Veena Das, V, Kleinman, A, Ramphele, M and Pamela Reynolds 
(eds). Berkeley: University of California Press, pp 205-225.

Foucault, M. 2005. The Hermeneutics of the Subject, Lectures at the College de France 198182. Tr. Graham Burchell. New York: Palgrave Macmillan.

Goldstein, R. 2001. Conversations in Bambara, French and English in Mali.

Haraway, D. 1991. Cyborg Manifesto: Science, Technology, and Socialist Feminism in the late 20th Century and Situated Knowledges: The Science Question in Feminism and the Privilege Partial Perspective. In Simians, Cyborgs and Women: The Reinvention of Nature. New York: Routledge.

Hirschkind, C. 2006. The Ethical Soundscape: Cassette Sermons and Islamic Counterpublics. New York:Columbia University Press.

Lambek, M. 2003. Forward to Wendy James' Ceremonial Animal. 2003. Oxford: Oxford University Press.

Mauss, M. 1973 [1934]. Techniques of the Body. Economy and Society 2(1): 70-87.

Obermeyer, C. and Reynolds, R. 1999. Female Genital Surgeries, Reproductive Health and Sexuality: A Review of the Evidence. Reproductive Health Matters 7(13) 112-120.

2005. The Consequences of Female Circumcision for Health and Sexuality: An Update on the Evidence Culture, Health \& Sexuality 7(5): 443-461.

Pandolfi, M. 1990. "Boundaries inside the body: women's sufferings in southern peasant Italy." CMP (14): 255-274.

Parker, M. Rethinking Female Circumcision. Africa: Journal of the International African Institute 65 (4): 506-523.

Povinelli, E. 2002. The Cunning of Recognition, Indigenous Alterities and the Making of Australian Multiculturalism. Durham: Duke University Press.

Rabinow, P. 2002. "Midst anthropology's problems" Cultural Anthropology. 17(2): 135-49.

Shell-Duncan, B. 2008. From Health to Human Rights: Female Genital Cutting and the Politics of Intervention. American Anthropologist 110(2): 225-236.

Shweder, R. 2000. What about "Female Genital Mutilation"? And Why Understanding Culture Matters in the First. Daedalus 129: 4. The End of Tolerance: Engaging Cultural Differences. 
Websites:

http://www.aaanet.org/committees/ethics/ethcode.htm

http://afropop.org/multi/feature/ID/40/Oumou\%20Sangare\%20speaks\%20out\%20about\%20w omens\%20issues. $\% 20 \% 2012 \% 202000$ ).

http://www.bbc.co.uk/radio3/worldmusic/onlocation/mali oumousangare.shtml

http://www.maliweb.net/category.php?NID=50722

http://www.maliweb.net/category.php?NID=49991\&intr=

http://news.bbc.co.uk/2/hi/africa/8216568.stm

http://www.un.org/womenwatch/daw/beijing/platform/plat1.htm\#statement

http://www.who.int/mediacentre/factsheets/fs241/en/

\section{About the Author}

Ruth Goldstein is a PhD candidate in the Department of Anthropology at the University of California, Berkeley. She can be contacted at ruthegoldstein(AT)berkeley.edu.

\section{Endnotes}

${ }^{1}$ See Charles Hirschkind's "The Ethical Soundscape: Cassette Sermons and Islamic Counterpublics." In analyzing the impact of recorded sermons on the public and in the creation of counterpublics in the secular state of Egypt Hirschkind writes of an ocular centrism inherited and inculcated by Enlightenment thinking.

${ }^{2}$ Lambek, Michael in his forward to Wendy James' Ceremonial Animal. 2003. Oxford: Oxford University Press.

${ }^{3}$ Action for Equality, Development, and Peace The United Nations Fourth World Conference on Women, Beijing, China - September 1995.

${ }^{4}$ Human Rights: an anthropological reader. 2009. Ed by Mark Goodale. West Sussex: Blackwell Publishing.

${ }^{5}$ Duncan, Bettina Schell. 2008. American Anthropologist 110 (2): 226.

${ }^{6}$ Panel Chair Dr. Trevor H.J. Marchand helped to push the author's thoughts on the duality of her ethnographic positioning at the Exploring and Expanding Boundaries of Research Methods Conference that took place at the School for Oriental and African Studies October 31-November 1, 2008.

${ }^{7}$ Toubabou means a white person.

${ }^{8}$ Other sources have reported figures between 80 to 200 million women.

${ }^{9}$ See http://www.who.int/mediacentre/factsheets/fs $241 / \mathrm{en} /$. 
${ }^{10}$ So popular and so gendered is "bajaru" that when Barema ??, who helped to translate the lyrics in Bambara, his wife heard the song and started to dance to it, before having even heard the words.

${ }^{11} \mathrm{See}$ http://www.bbc.co.uk/radio3/worldmusic/onlocation/mali oumousangare.shtml, http://afropop.org/multi/feature/ID/40/Oumou\%20Sangare\%20speaks\%20out\%20about\% 20womens\%20issues.\%20\%2012\%202000.

${ }^{12}$ See http://www.maliweb.net/category.php?NID=50722, http://news.bbc.co.uk/2/hi/africa/8216568.stm, http://www.maliweb.net/category.php?NID=49991\&intr=.

${ }^{13}$ See http://news.bbc.co.uk/2/hi/africa/8216568.stm.

${ }^{14}$ See http://www.maliweb.net/category.php?NID=50722, http://news.bbc.co.uk/2/hi/africa/8216568.stm, http://www.maliweb.net/category.php?NID=49991\&intr=

${ }^{15}$ Conversations with Nancy Scheper-Hughes 2009. 